parents, both financially and in friendly relationships. However, the role of relationships with the opposite sex is not underestimated. According to the survey results before and after the experiment, we see that there is some difference between the indicators. Under the influence of the lessons we developed during the year, students experienced positive changes, after the experiment students changed their priorities a bit: they began to appreciate their health and health of other people. Therefore, based on the data obtained, we see that after the experiment, motivation for a healthy lifestyle is higher, which indicates the positive result and effectiveness of the program we have developed.

Key words health promotion, preservation of health, health saving, value attitude to health, means of physical therapy, Physical Education, physical performance.

удк 378.147.091.398:008-022.218:811.161.1

Валентина Стативка

Институт иностранных языков и литературы

Ланьчжоуского университета (KHP) ORCID ID 0000-0001-7261-6785

DOI 10.24139/2312-5993/2019.08/319-337

\title{
ТЕКСТОВО-ДИСКУРСИВНАЯ КАТЕГОРИЯ СИТУАТИВНОСТИ: ЛИНГВО-МЕТОДИЧЕСКАЯ ПРОЕКЦИЯ
}

В статье осуществляется анализ и отбор лингвистической информации о текстово-дискурсивной категории ситуативности для иностранных магистрантов-филологов; презентуется разработанная автором методика формирования одной из основных составляющих профессиональной компетенции филолога - умения анализировать текстовые категории (на материале ситуативности). Теоретическая информация из области лингвистики текста содержит как общепринятые, так и дискуссионные положения, что позволит преподавателю и магистрантам организовать на занятии научную дискуссию вокруг поднимаемой проблемы - объема текстовой категории ситуативности. Разработанный комплекс упражнений используется как в самостоятельной, так и коллективной познавательной деятельности, он подчинен обогащению научного лексикона, синтаксического строя речи иностранных магистрантов и формированию умений анализа текстовых категорий.

Ключевые слова: лингвистика текста, категория ситуативности, коммуникативная ситуация, рефреренциальность, антропоцентричность, комплекс упражнений, анализ текстовой категории

Постановка проблемы. Текст - это средство коммуникации, воздействия, доставления эстетического наслаждения, а значит, по своей природе он ориентирован на человека воспринимающего, что предопределяет создание текста с учетом сферы и среды, в которых он будет восприниматься. Автор отбирает элементы содержания и языковые средства, компонует их в определенной последовательности, позволяющей ему реализовать коммуникативную установку. Это значит, что комплекс экстралингвистических условий определяет отбор содержания и характер языковой ткани, выбор жанра и стиля. 
Следовательно, текст прочно связан с социальной средой и сферой коммуникации. Т. Ван Дейк отмечает, что «связные тексты вроде рассказа о каком-либо происшествии не существуют в вакууме. Они производятся и воспринимаются говорящими и слушателями в конкретных ситуациях, в рамках широкого социокультурного контекста» (ван Дейк, Кинч, 1988, с. 8). Ученый рассматривает текст как феномен дискурса, т.е. социальнокоммуникативной ситуации, в которой рождается и завершается текст. Следовательно, в тексте отражается эта ситуация, а значит, текст обладает таким существенным признаком, как ситуативность.

Ситуативность как текстово-дискурсивная категория наиболее последовательно и полно описана в работах по функциональной стилистике, лингвистике текста и теории коммуникации (В.Г. Гак (Гак, 1988), К.А.Долинин (Долинин, 1999; 2007), В. И. Карасик (Карасик, 2004; 2007), М.Н.Кожина (Кожина), В. Г. Костомаров (Костомаров, 2005), В.В.Красных (Красных, 1997) и др. - представляют составляющие ситуации общения, особенности их характеристики; О. Воробьева (Воробьева, 1993), Е. А. Селиванова (Селиванова, 2002), 3. В. Тураева (Тураева, 2009) - поднимают вопросы иерархии текстовых категорий и подкатегорий, детализируют категориальные свойства текста, в том числе и соотносимые с ситуативностью.

Появление все новых и новых категорий, описываемых лингвистами, говорит о расширении и углублении лингвистической теории текста, и в этой ситуации методистам необходимо осуществлять отбор сведений о текстовых категориях, доступный и имеющий практическую значимость для формирования профессиональной компетенции, в состав которой входят умения анализа текстовых категорий.

В этой связи целью данной статьи стал анализ лингвистических сведений о текстово-дискурсивной категории ситуативности, отбор базовых сведений и создание комплекса упражнений для формирования основы профессиональной компетенции иностранного магистра-филолога - умений анализа категорий текста. Основной метод исследования вопроса - анализ лингвистических концепций текстовых категорий, обобщение и систематизация основных положений, составляющих базу для формирования умений анализа текстовых категорий (на материале категории ситуативности).

Изложение основного содержания. Ситуативность как категория текста многогранна, потому что это свойство напрямую предопределяется сложностью коммуникативного акта. В. В. Красных в каждом коммуникативном акте отмечает четыре аспекта:

1) экстралингвистический аспект: конситуация - объективно существующая собственно экстралингвистическая ситуация общения; условия (в самом широком смысле) общения и его участники (т.е. кто, что, где, когда);

2) семантический аспект: контекст - имплицитно или эксплицитно выраженные смыслы, реально существующие, являющиеся частью 
ситуации, отражающиеся в дискурсе и актуальные для данного коммуникативного акта;

3) когнитивный аспект: пресуппозиция - зона пересечения индивидуальных когнитивных пространств (фондов знаний коммуникантов), включая и представления коммуникантов о конситуации;

4) собственно лингвистический аспект: речь - продукт непосредственного речепроизводства, то, что продуцируют коммуниканты (Красных, 1997, с. 24). А поскольку текст является продуктом коммуникативной деятельности, то в нем отражаются все аспекты коммуникативного акта.

Так что же такое ситуативность как категория текста? Долинин пишет: «По поводу любого текста мы всегда можем спросить: кто именно, кому, где, когда, в каких конкретно обстоятельствах и каким конкретно способом адресует данное сообщение» (Долинин, 2007, с. 9). Другими словами, текст содержит в себе такие показатели, по которым можно сориентироваться в ситуации производства или восприятия речи. Значит, cumyamuвность - это свойство текста отражать коммуникативную ситуацию, комплекс тех экстралингвистических условий, под воздействием которых происходит порождение и восприятие текста. Рассмотрим более детально, что же составляет коммуникативную ситуацию.

«Под коммуникативной ситуацией будем понимать сложный комплекс внешних условий общения и внутренних состояний общающихся, представленных в речевом произведении, направляемом адресату», - так определяет содержание коммуникативной ситуации Н. И. Формановская. Она выразила сущность, повторяющуюся во множестве научных дефиниций этого понятия. Однако степень конкретизации условий, составляющих коммуникативную ситуацию, в научных описаниях не одинакова (В.Г. Гак (Гак, 1998), Н. И. Формановская (Формановская, 2007), В. И. Карасик (Карасик, 2004; 2007), В.Г. Костомаров (Костомаров, 2005). Нам кажется наиболее полным и структурирующим представление реципиента о ситуации общения определение, данное этому феномену В. И. Карасиком: «Категории ситуации общения: 1) участники общения (статусно-ролевые и ситуативнокоммуникативные характеристики); 2) условия общения (пресуппозиции, сфера общения, хронотоп, коммуникативная среда); 3) организация общения (мотивы, цели и стратегии, развертывание и членение, контроль общения и вариативность коммуникативных средств); 4) способы общения (канал и режим, тональность, стили и жанр общения)» (Карасик, 2007). Под статусноролевыми характеристиками участников имеются в виду статусное положение в социуме (ректор - преподаватель - студент) и конкретная роль в обыденной или официальной ситуации (продавец - покупатель), при этом на характер взаимодействия влияют и степень знакомства, и общий контекст, и общие фоновые знания. Психологическая роль коммуникантов отражает 
роль в конкретной группе, например, семье (родители - дети, старший младший), среди друзей (лидер, аутсайдер, покровитель, защитник, друг) и соотносится с носителем определенного эмоционально-психического состояния, темперамента, мировоззрения, вкусов и привычек.

Кроме адресата и адресанта в антропологический центр ситуации общения могут входить такие компоненты, влияющие на характер течения дискурса, как наблюдатель - присутствующий, но не имеющий права вмешиваться в разговор (например, зритель, слушатель, присутствующиее на дебатах кандидатов в президенты). На него ориентирован текст, поэтому и характер речевого продукта в определенной мере зависит от этого компонента ситуации.

Каждый участник речевого взаимодействия или наблюдатель обладает определенным уровнем фоновых знаний (или пресуппозицией), который позволит понять и интерпретировать получаемую информацию. Пресуппозиция - это те сведения о мире, «которые дадут им (коммуникантам - вставка наша С.) возможность держаться в процессе коммуникации известных обоим ориентиров и границ» (Клюев, 2002, с. 8586). 3. Я. Тураева определяет пресуппозицию как сумму фоновых знаний. Эти предполагаемые знания могут иметь характер энциклопедических, но может ожидаться и наличие более глубоких, специальных знаний (Тураева, 2009, с. 47). Выделение И. Я. Чернухиной таких видов пресуппозиций, как универсальная, культурная, социальная, профессиональная, и речевая, говорит об области и широте ожидаемых у адресата знаний (Чернухина, 1990). Учет пресуппозиции позволяет адресанту строить текст из расчета на знание адресатом исходных положений, условий, личностей, событий, которые могут всплывать в контексте, на способность адресата извлечь различные виды информации. Объем извлеченной подтекстовой информации (в художественных текстах) предопределен отчасти степенью глубины и широты пресуппозиции рецепиента. Общеизвестно, что из текста извлекается СПИ (содержательно-подтекстовая информация) благодаря знанию языка и действительности (символических значений слов и предметов, возникновению ассоциативных, логических, образных связей и др.), которые формируются в опыте языкового существования.

Ориентация на адресата, его пресуппозицию детерминирует многие условия создания текста: где будет восприниматься текст (выбор сферы деятельности), особенности содержания и языка, тональность изложения (официальная, дружеская, лирическая, ироническая, обличительная, враждебная, агрессивная и т.д.). Выбирая тему, давая заглавие тексту, определяясь в способе и тональности изложения, автор, в сущности, выбирает жанр текста, законы которого позволят реципиенту понять и интерпретировать текст, а жанровые формы сами по себе «стабильно закреплены за определенной сферой общения и тем или иным типом 
коммуникативной ситуации» (Воробьева, 1993, с. 163). Таким образом, жанровая принадлежность текста обусловлена ситуативно.

Более-менее объективная интерпретация текста читателем требует фоновых знаний, выходящих за пределы конкретного текста, то есть речь идет о широком контексте. Под широким контекстом Б. М. Гаспаров имеет в виду «факторы, сопутствующие вербальной коммуникации. Это и ситуация общения, и совокупность культурных и социальных условий, в которых совершается коммуникация, сетка контекстов, в которую включается данный текст, - контекст эпохи, литературного направления, жанра, индивидуальной авторской системы и т.д. Такое понимание контекста смыкается с тем, что О. С. Ахманова определяет как вертикальный контекст, В.Я. Мыркин - как коммуникативный контекст, Г.В.Колшанский - как сетку контекстов, чешская исследовательница Слама-Козаку - как глобальный контекст» (Гаспаров, 1996, с. 67). И. Т. Касавин предлагает назвать его контекстом культуры: «Ведь адекватное понимание всякой интеракции требует фонового знания (background knowledge), которое выходит далеко за пределы локального разговора и непосредственного окружения» (Касавин, 2008, с. 234). Следовательно, создание и восприятие текста обусловливается историкокультурным контекстом.

Рассмотрение текста в условиях историко-культурного контекста, в экстралингвистических условиях конкретной коммуникативной ситуации, которые влияют на создание и восприятие текста, говорит о невозможности понимания категорий текста вне связи с жизнью, то есть вне дискурса, составляющей которого он является. В этой связи категория cumyamивности текста может быть истолкована как обусловленность порождения и восприятия текста экстралингвистическими факторами, коммуникативными условиями и историко-культурным контекстом.

Некоторые ученые не выделяют ситуативность как текстоводискурсивную категорию, но описывают такие категории, которые тем или иным образом отражают ситуативные свойства текста. Так, например, О. П. Воробьева (Воробьева, 1993, с. 42), И. М. Колегаева (Колегаева, 1991, с. 18), Е. А. Селиванова (Селиванова, 2002, с. 227) в ряду текстово-дискурсивных категорий выделяют референциальность и антропоцентричность, которые тесно смыкаются с категориями целостности и ситуативности.

Референциальность, понимаемая в лингвистике как соотнесенность текста с некоторым сегментом реальности или квазиреальности, неким положением дел, с референтной ситуацией или событием (Гаспаров, 1996, с. 42), с нашей точки зрения, может восприниматься как составляющая категории ситуативности, поскольку она отражает обстановку коммуникации в тексте. Е. А. Селиванова считает, что сущность этой категории сложнее и понять ее можно, если принять за исходное наличие различных точек референции. Точками референции в дискурсе являются: 1) авторское 
порождение текста на основе интериоризации им бытийной сферы, пространства и времени, в которые он погружен; 2) соотнесение авторской интериоризации с референцией событий, явлений, описываемых в тексте (другими словами, соотношение картины реальности, которую ощущает автор, с той картиной, которая получилась в тексте, то есть с виртуальным пространством текста); 3) читательская референциальная соотнесенность со своей эпохой во времени и пространстве и 4) референция читательской рецепции описываемых в тексте фактов, событий, то есть актуальное виртуальное пространство текста (Селиванова, 2002, с. 227). Отразим точки референциальности в виде схемы:

Автор и мир, окружающий его

Читатель и мир, окружающий его
Созданный автором в тексте мир (виртуальное пространство)

Отраженный сознанием читателя - мир текста (актуальное виртуальное пространство текста)

Референция текста бывает разной степени приближенности к жизни. Спепень ее приближенности зависит в первую очередь от стиля и жанра. Е.И. Селиванова выделяет на этом основании разные виды референциальности: максимальной приближенности к действительности (деловые документы, акты, автобиография, хроника, репортаж); пунктирную референцию, состоящую в выборе отдельных реальных событий, исторических личностей (исторические романы, биографическая проза, теледискурс, политический дискурс); референцию-рефлексию (лирические произведения); референцию вымысла (художественные тексты с вымышленными событиями, героями); референцию-фэнтэзи (в большей или меньшей степени отдаленные от реального мира «фантастические» тексты: сказки, триллеры, фантастика) (Селиванова, 2002, с. 227-228).

Если понимать референцию как соотнесенность с действительностью или ее отрезком, то ее можно рассматривать и в составе целостности, которая и предопределяется связностью самих явлений отраженной в тексте действительности. Если референциальность зависит от стиля и жанра, от авторской стратегии, интерпретанты читателя, фонда его знаний, эпохи, в которую он живет, от языка и культуры, в которую он погружен; от отдаленности эпохи порождения текста и времени восприятия, эпохи интерпретанта, то речь идет о роли коммуникативной ситуации, а именно таких ее условий, как адресат и адресант, их коммуникативной интенции, пресуппозиции, о контексте (культурно-историческом, ситуативном), об условиях восприятия текста. Другими словами, речь идет о той части свойств, которые соотносятся с ситуативностью как текстово-дискурсивной категорией, традиционно выделяемой в лингвистике текста.

Категория антропоцентричности состоит в признании человека, его сознания гносеологическим и коммуникативным центром дискурса и текста. 
В художественном произведении таких центров три: автор, читатель и персонаж (Тураева, 2009; Красных, 1997; Гаспаров, 1996). По мнению Е.А. Селивановой, антропоцентризм проявляется в значительно большей разноплановости диалогических связей. Автор и читатель неодноплановы, и поэтому выделяет подкатегории адресантности $u$ адресатности. Категория адресантности включает: а) личность автора как человека, творящего текст; б) автор в тексте, с которым можно вести внутренний диалог (автор-функция - 3. Я. Тураева (Тураева, 2009, с. 82). «Автор-функция может быть имплицитен, однако сфера его мыслей, оценок, эмоций, чувств и т.д. просвечивает сквозь текстовую ткань в глобальной связности дискурса. Эксплицитный автор-функция может соответствовать образу автора, представленному знаками личных, притяжательных местоимений, глаголами, вводными словами и т.д.» (Селиванова, 2002, с. 229).

Категория адресантности также представлена образом рассказчика (например, Максим Максимович в «Герое нашего времени» М. Ю. Лермонтова, Белкин в «Повестях Белкина» А. С. Пушкина); в лирических произведениях - лирическим героем. При этом автор-функция не может быть отождествлен с персонажем в лирике, хотя какой-то отпечаток автора на лирическом герое признается, но все же лирический герой скорее относится к персонажным антропоцентрам.

Второй подкатегорией антропоцентричности является адресатность. В тексте всегда отражается ориентация автора на потенциального читателя, его способность к интерпретации и другие свойства. Автор представляет себе тот идеал читателя, на восприятие которого он рассчитывает и с учетом понимания которого создает художественный текст, то есть создает модель идеального адресата. Однако читают текст зачастую не совсем такие читатели, которых себе представляет автор. Кроме того, иногда автор создает образ фиктивного читателя и включает его в текст, ведя с ним диалог. Значит, подкатегорию адресатности составляет: а) идеальный адресат (адресатфункция, как называют его 3. Я. Тураева, Е. А. Селиванова и др.); б) реальный адресат (человек, читающий или слушающий); в) фиктивный читатель (придуманный и введенный в текст автором).

Смоделированный идеальный адресат, или адресат-функция, может вступать в диалог с автором-функцией. «Однако этот диалог не следует смешивать со взаимодействием образа автора с образом читателя (фиктивного читателя), как, например, у Н. В. Гоголя: «Тут скажут многие читатели и укорят автора в несообразностях... Читателю легко судить, глядя из своего покойного угла...». Диалог автора-функции и адресатафункции прослеживается на всем информационном пространстве и нередко коррелирует с текстовым концептом» (Селиванова, 2002, с. 232). Конкретный адресат-человек пропускает сквозь призму своего сознания адресата-функцию, даже вступая в диалогические отношения с ним. 
Иногда, как отмечают ученые, адресат-функция может не совпадать с созданной автором идеальной моделью, как это произошло с произведениями Ф.Купера, А.Дюма, Д. Дефо, изначально ориентированных на взрослого читателя, а с течением времени превратились в чтение для детей и юношества (Колегаева, 1991, с. 19-20).

Диалог с реальным читателем, вовлечение его в диалогические отношения осуществляется средствами внешней диалогизации (обращений, форм императива, вопросительных предложений и др.).

Категория антропоцентричности, которая, согласно Е. А. Селивановой, включает подкатегории адресантности и адресатности, также как и категория референции по своей сути может соотноситься с категорией ситуативности, относимой к семи важнейшим текстовым категориям, описанным еще Бограндтом и Дресслером и получившим дальнейшее развитие в коммуникативной лингвистике, лингвистике текста и стилистике (И. М. Вознесенская (Вознесенская, 2011), В.Г. Костомаров (Костомаров, 2005), М. Н. Кожина (Кожина) и др.). Поскольку в науке утвердилось мнение о том, что рассмотрение текста как «результата», самодостаточного герметичного образования недостаточно (Карасик, 2007, с. 227), то текст воспринимается и как результат и как процесс, то есть как составляющая дискурса. Возникает потребность в учете всех обстоятельств, условий порождения текста: адресанта и адресата, сферы и обстановки, в которой происходит речевое взаимодействие и т.д. Эти условия описаны в стилистике как экстралингвистические стилеобразующие факторы. К ним относят сферу общения, связанную с видом деятельности (наука, искусство, политика, право, религия, бытовая сфера), форму мышления (логикопонятийное, образное, деонтическое и др.) цель общения, тип содержания, функции языка (коммуникативная, эстетическая, экспрессивная, фатическая и т.д.), типовую ситуацию общения (официальная/неофициальная) (Кожина). М. Н. Кожина перечисляет и другие (условно вторичные) факторы, от которых зависит стиль текста, - это условия общения и формы речи, своеобразие аудитории, опосредованное или непосредственное общение, устная или письменная речь, вид общения, специфика жанра, индивидуальная интенция и др. В. Г. Костомаров (Костомаров, 2005, с. 45), вводя в качестве экстралингвистических стилеобразующих факторов понятия сферы и среды, вкладывает в понятие «сфера» то же содержание, что и М.Н. Кожина, а понятие «среда» наполняет таким содержанием: это общающиеся люди, с их характерами и статусом, способами и видами контактов, взаимоотношениями и интересами. По мнению ученого, характер соотношения сферы и среды определяет особенности ситуации общения, которая в свою очередь определяет тип текста: книжный, разговорный или массово-коммуникативный. В книжных специализированных типах текста (научной статье, законе, деловых документах) будет доминирующим 
фактором сфера, а в других неспециализированных книжных текстах (например, в мемуарах), а также массово-коммуникативных и разговорных доминирующим стилеобразующим фактором будет среда.

Следовательно, ситуативность - текстообразующая категория, в состав которой входит множество аспектов, в том числе и те, о которых говорится при характеристике референциальности и антропоцентричности. Более того, В. Г. Гак, говоря о соотнесенности высказывания с ситуацией (под которой он имеет в виду совокупность элементов, присутствующих в сознании говорящего в объективной действительности в момент говорения и обусловливающих в определенной мере отбор языковых элементов при формировании самого высказывания (Гак, 1998, с. 246) акцентирует внимание на том, что именно структура денотата (или референта) составляет ядро речевой ситуации. При этом ученый подчеркивает, что высказывание отражает не только предметные отношения, но и информированность собеседников (отражаемую актуальным членением) и позицию говорящего (отражаемую категориями модальности)... (Гак, 1998, с. 246). Если трансформировать особенности ситуативности высказывания в область целого текста (такая трансформация нам представляется правомерной, так как высказывание представляет собой структурную единицу текста, текст в миниатюре), то референциальность вполне можно считать аспектом текстовой категории ситуативности. Хотя выявление четкой грани между содержанием категориальных признаков референциальности, антропоцентричности, ситуативности невозможно, они соприкасаются, вступают в отношения конкретизации с разными категориями (ситуативности, целостности, модальности и др.), образуя текст.

В результате анализа мнений исследователей категории, приходим к выводу, что под ситуативностью следует понимать свойство текста быть созданным под воздействием ситуации общения (участники общения, условия общения, организация общения, способы общения), широкого контекста (контекст эпохи, литературного направления, жанра, индивидуальной авторской системы и т.д.) и отражать их в языковой ткани.

Проанализируем категорию ситуативности в художественном тексте (на материале рассказа И. Бунина «Молодость и старость»).

Художественное произведение отражает ряд экстралингвистических условий, под влиянием которых оно создавалось и должно (предположительно) восприниматься: тема, коммуникативная установка автора, особенности предполагаемого адресата, сфера (искусство), доминирующая функция текста (доставление эстетического наслаждения), тип отражаемой реальности и, соответственно, тип речи, вид речи и др., что в комплексе составляет ситуацию общения. Значит, при анализе ситуативности как категории текста требуется выяснить, какую конкретно ситуацию общения отражает текст. 
Произведение было создано в 1936 году, в зрелый период жизни писателя, за 17 лет до смерти. Обычно многие писатели прибегают к лаконичному жанру миниатюры (И. С. Тургенев, Ю. Бондарев, В. Астафьев и др.) на исходе лет, когда состояние здоровья не позволяет верить в завершение произведения большого жанра. И. Бунин же - мастер рассказа, это его жанр, писатель заявил так о себе с первых публикаций («Храм солнца» (1907), «Суходол» (1912), «Иван Рыдалец» (1912-1913) и др.

Рассказ «Молодость и старость» навевает воспоминания о путешествии писателя по востоку в 1907 г.: Сирия, Иран, Египет... Вероятно, потому, что в основе рассказа - восточная притча.

Несмотря на время написания (30-е годы XX столетия), в тексте отражена эпоха начала XX века, смутное время бесконечных военных действий в Турции, время первой мировой войны. Такое состояние в обществе высвечивает истинно ценные человеческие качества и становится очевидным пафосный «словоблудливый» патриотизм. Наверное, потому автор и обращается к этому времени, но не к положению в стране, а к человеку, тем ценным и достойным уважения качествам, которые в нем могут быть.

Анализ категории ситуативности, вбирающей в себя референцию соотнесенность с действительностью или ее отрезком - позволяет увидеть время, место и человека.

В данном тексте вымышленная референция - вымышленные события, персонажи, однако они тесно связаны с историческими событиями отражаемого объективного времени - положение военного противостояния Турции как внутри страны, так и на международной арене в начале XX века. Пространство - открытое, географическое - поездка погожим летним днем вдоль побережья Черного моря: из Крыма в Турцию на теплоходе, перегруженном пассажирами самых разных социальных слоев. Референцию составляет отрезок виртуальной действительности, который постепенно наполняется предметами, значимыми для представления коммуникативной среды и наблюдателей: каюты первого класса и прохладный бриз в них; палуба для всех остальных - грязь, теснота, орда разноплеменных палубных пассажиров, горячая машина, пахучая кухня, якорные цепи, канаты, баки и т.д. В таких поездках происходят зачастую неожиданные встречи с интересными или незаурядными людьми, что и наблюдаем в тексте. Коммуникативная среда, на фоне которой происходит диалог персонажей, достаточно пестрая, наблюдателями в акте коммуникации персонажей могут быть и «русские мужики и бабы, хохлы и хохлушки, афонские монахи, курды, грузины, греки...», это усредненная и не всегда образованная публика. Автор как бы хочет сказать, что содержание текста адресовано любому из них (тем более, что все они праздны в поездке и могут слышать диалог), 
произошедший на палубе. Жанр притчи, лежащий в основе диалога, сам по себе рассчитан на восприятие широкой специально неподготовленной публикой, как часто и было в истории: притча звучала из уст религиозного проповедника. Но здесь притча вошла в жанр рассказа!

Антропоцентрами данного текста является автор-функция, называющий себя «я» (от его имени ведется повествование, через его сознание отражается увиденное, а язык текста подсказывает, что он интеллигентный, образованный, наблюдательный человек, способный корректно дать оценку происходящему), персонажи (их два - пожилой курд и молодой богатеющий и полнеющий господин, керченский грек - люди разного возраста, социального положения, социального опыта и, как станет известно из текста, разного ментального склада). Третий антропоцентр читатель. Если говорить об идеальном читателе, которого себе представляет автор, то таковым может стать любой, даже заурядный человек, способный извлечь подтекст как из очень прозрачной по содержанию притчи, включенной автором в текст и составляющей его основную часть, так и из самого рассказа. Поучительный смысл лежит на поверхности, поэтому богатых фоновых знаний не требуется для понимания смысла текста.

Данный текст относится к сфере искусства, его основная функция оказать воздействие и доставить эстетическое наслаждение воспринимающему, поэтому потребует от реципиента образного мышления: дорисовки в воображении происходивших событий, чувств и переживаний гордого старика, утратившего семерых сыновей на войне. Текст рассчитан на восприятие в нейтральной обстановке, скорее в бытовых условиях, но не в официальных.

Создавая текст, автор имел определенную коммуникативную установку, которая, вероятно, состояла в том, чтобы и мудрость жизненную передать, и доставить наслаждение читателю от мастерски созданного текста.

Язык и содержание позволяют определить особенности реализации категории ситуативности в тексте. Начало повествовательного художественного текста выполняет функцию введения в ситуацию и представляет собой зачин-картину с пунктирным развертыванием содержания. Односоставные номинативные предложения лаконично обрисовывают пространство (где?), время (когда?), позволяя каждому читателю дорисовать картину на основе своего опыта более конкретно. Авторский способ развертывания содержания, лаконичный и в то же время динамичный, не дает «заскучать» усредненному читателю, обычному обывателю, на восприятие которого рассчитано произведение:

«Прекрасные летние дни, спокойное Черное море.

Пароход перегружен людьми и кладью, - палуба загромождена от кормы до бака.

Плавание долгое, круговое - Крым, Кавказ, Анатолийское побережье, Константинополь... 
Жаркое солнце, синее небо, море лиловое; бесконечные стоянки в многолюдных портах с оглушающим грохотом лебедок, с бранью, с криками капитанских помощников: майна! вира! - и опять успокоение, порядок и неторопливый путь вдоль горных отдалений, знойно тающих в солнечной дымке».

Параллельное построение предложений, развернутое бессоюзное предложение с ощутимыми паузами между равномерными синтагмами придают ритм прозе, и зачин воспринимается на одном дыхании.

Место действия прояснено. В свойственной И. Бунину реалистической манере, но в то же время полной поэзии жизни, автор знакомит читателя со средой, на фоне которой будет разворачиваться эпизод: она представляет собой разнонациональную простонародную среду, поэтому язык соответствует ситуации: реплики пожилого курда лаконичны, просты и доступны по содержанию, они передают манеру речи проживающих на юге России и Кавказе людей, для которых русский язык неродной. В основном эпизоде рассказа создается впечатление характерологического повествования: один повествователь (авторфункция) сменяется другим и все внимание переключается на него как антропоцентр текста. Он центр и он - носитель мудрости.

«- Какой глупый, - ответил он просто. - Вот ты будешь старый, а я не старый и никогда не буду. Про обезьяну знаешь?

Красавец недоверчиво улыбнулся:

- Какую обезьяну?

- Ну так послушай! Бог сотворил небо и землю, знаешь?

- Ну, знаю.

- Потом бог сотворил человека и сказал человеку: будешь ты, человек, жить тридиать лет на свете, - хорошо будешь, жить, радоваться будешь, думать будешь, что все на свете только для тебя одного бог сотворил и сделал. Доволен ты этим? А человек подумал: так хорошо, а всего тридиать лет жизни! Ой, мало! Слышишь? - спросил старик с усмешкой.

- Слышу, - ответил красавещ».

Реплики богатеющего грека, краткие и снисходительные, с проскакивающими ошибками («нету»), что характерно для этой социальной прослойки: есть деньги - недостает образования, культуры взвимодействия, о чем говорит бестактное выражение снисходительной жалости:

«- Це, че, це! - с небрежным сожалением сказал стоявший над нами с папиросой в руке молодой полнеющий красавец и франт, керченский грек: вишневая дамасская феска, серый сюртук с белым жилетом, серые модные панталоны и застегнутые на пуговки сбоку лакированные ботинки. - Такой старый и один остался! - сказал он, качая головой».

Сюжет притчи легко вписывается в коммуникативную среду, отраженную в рассказе. В тексте все гармонично: содержание и язык находят своего адресата, а доступность текста для интерпретации усредненным читателем приводит к порождению у каждого основного смысла: человек должен всегда оставаться человеком, вопреки соблазнам и искушениям. 
Таким образом, на основе текста рассказа определяется тема, устанавливается сфера и среда общения, определяется функция текста, выводятся характеристики антропоцентров текста и т.д., значит, текст обладает такой категорией, как ситуативность.

Если обратить внимание на логику развертывания текста, представляющего собой анализ категории ситуативности, то можно установить такую последовательность: а) текст в контексте культуры, социальной обстановки и творчества писателя; б) предполагаемая коммуникативная установка автора; в) ориентация на читателя и как следствие воздействия этих факторов - выбор сюжета, жанра, референтного плана, коммуникативной среды, на фоне которой разворачивается событие и в которой, возможно, будет восприниматься художественное произведение; г) основные функции текста и соответствие им языка изложения.

Последовательность анализа может варьироваться, однако содержание анализа текстово-дискурсивной категории ситуативности подчиняется выявлению вертикального (широкого) контекста и условий коммуникативной ситуации.

При разработке системы упражнений для формирования иностранных магистрантов-филологов умений анализа категории ситуативности мы учитывали поиски и наработки в этом аспекте методики (А. М. Стативка, Т. В. Мовчан), но в результате предлагаем новый комплекс упражнений.

Текст для магистрантов, содержащий теоретические сведения о категории информативности, представляет собой предельно сжатую (до 34 страниц) и минимизированную информацию. (В статье мы не имеем возможности его представить ввиду ограничений в объеме). К тексту предлагаются вопросы и одно несложное задание, посильное для выполнения за короткий срок, но демонстрирующее степень усвоения материла. Например:

1. В чем заключается сущность категории ситуативности? (Прочитайте определение).

2. Какие условия составляют коммуникативную ситуацию? (Перечислите по памяти).

3. Может ли антропоцентричность, проявляющаяся в адресантности и адресатности, составлять содержание категории ситуативности? (Размышляйте и аргументируйте).

4. Входит ли референция в содержание ситуативности? (Размышляйте и аргументируйте).

5. Что такое вертикальный контекст? (Воспроизведите по памяти и прочитайте)

6. Прочитайте миниатюру И. Бунина «Капитал» и проанализируйте ситуативность текста, размышляя в такой последовательности: эпоха, 
творчество писателя, что, где, кому, с какой целью, какова связь между коммуникативной ситуацией и выбором языковых средств?

\section{Задания для выполнения в самостоятельной учебно- познавательной деятельности.}

Упр. 1. Прочитайте текст миниатюры Ю. Бондарева «Женственность». Выделите и переведите незнакомые слова.

Упр. 2. Прочитайте тексты для формирования фоновых знаний. (Для чтения предлагаются документальные сведения о зверствах фашистов на оккупированных территориях. Содержание этих текстов формирует фоновые знания реципиента, необходимые для понимания смысла текста Ю. Бондарева).

Упр. 3. Установите коммуникативную ситуацию на основе текста Ю. Бондарева: О чем текст? Какой фрагмент действительности (референциальность) отражен в тексте? От какого лица и когда ведется повествование? На какого читателя рассчитывает автор? В каких условиях может восприниматься текст? Какова цель создания текста и какова его функция? Соответствуют ли языковые средства установленным вами условиям коммуникативной ситуации?

Упр. 4. Прочитайте. Прокомментируйте каждое положение ученого и приведите примеры из текста Ю. Бондарева.

Речевые особенности текстов обусловлены ситуативно, то есть предопределены как сферой - предметно-тематической областью, так и средой - реальными коммуникативными условиями общения и, что важно, характеристиками субъектов речи. При порождении текста выявленные факторы ситуативности мотивируют использование определенных речевых средств, которые выступают в качестве маркеров, индикаторов ситуативности (И. М. Вознесенская).

\section{Задания для работы на занятии:}

Упр. 5. Переведите выражения:

Лицо, склоненное над рацией; блиндаж начальника штаба дивизиона; керосиновые лампы; бурно клокочущее пламя из раскрытой дверцы железной печки; волны обжитого на короткий срок покоя; над накатами звезды декабрьской ночи; успокоенность сонного человеческого часа; под накатами, лежали мы на нарах; дремотная паутинка.

Упр. 6. Слушайте, повторяйте и последнее предложение запишите по памяти.

1. Каждый текст дает возможность установить. Каждый текст дает возможность установить не только, о чем в нем говорится. Каждый текст дает возможность установить не только, о чем в нем говорится, но и кто говорит (автора-функцию), кому говорит (читателя), зачем говорит (коммуникативную установку и функцию текста) и другие условия коммуникативной ситуации. 
2. Свойство текста отражать условия порождения и восприятия текста называют ситуативностью. Свойство текста отражать экстралингвистические, когнитивные условия порождения и восприятия текста называют ситуативностью.

3. Категория ситуативности не является изолированной от других свойств текста. Категория ситуативности не является изолированной от других свойств текста, а пересекается с категориями референциальности, антропоцентричности. Категория ситуативности не является изолированной от других свойств текста, а пересекается с категориями референциальности, антропоцентричности, которые были описаны учеными позже, чем ситуативность.

4. Кроме экстралингвистических факторов, составляющих ситуацию общения... Кроме экстралингвистических факторов, составляющих ситуацию общения, не менее важными для адекватного понимания текста являются когнитивные условия. Кроме экстралингвистических факторов, составляющих ситуацию общения, не менее важными для адекватного понимания текста являются когнитивные условия: пресуппозиция читателя (фоновые знания) и знание вертикального контекста (контекста эпохи, литературного направления, авторского идиостиля).

5. Приступая к анализу ситуативности текста, определим вертикальный контекст, а затем выявим экстралингвистические факторы: что, где, кому, зачем (с какой целью) говорится - и соотнесем эти факторы с выбором языковых средств.

Упр. 7. Выразительно перечитайте миниатюру Ю. Бондарева «Женственность». Используя освоенные речевые средства, проанализируйте ситуативность текста, отвечая на вопросы и выполняя задания:

1. Установите вертикальный контекст произведения: Когда оно было написано и какую эпоху отражает? Какое место в творчестве автора занимает жанр миниатюры?

2. Какова, предположительно, коммуникативная установка автора?

3. Какова доминирующая функция текста?

4. Какова референциальность (отрезок действительности) в тексте?

5. На какого читателя, по-вашему, рассчитывает автор? Опишите антропоцентры (повествователь- персонажи- читатель) в тексте.

6. Проанализируйте язык текста-миниатюры и докажите, опираясь на ситуативность как категорию текста, что выбор коммуникативных средств соответствует замыслу ( теме, концепту и коммуникативной установке автора).

Выводы. Проанализировав основные лингвистические и лингвометодические работы, которые соотносятся с поднимаемой в статье проблемой - определение объема категории ситуативности - мы приходим к 
выводу: ситуативность - глобальная текстовая категория, которая пересекается со многими категориями и подкатегориями (например, референциальностью, антропоцентричностью, пространством и временем, интенциональностью) и поэтому в тексте они взаимодействуют, дополняя одна другую. В процессе анализа ситуативности неизбежно приходится говорить в связи со сферой общения о пространстве и времени, о референциальности; в связи со средой общения - об антропоцентричности адресанте и адресате, пресуппозиции реципиента, о наблюдателе и т. д. Такое понимание ситуативности расширяет объем ее содержания и отражается на характере анализа.

Разработанный комплекс упражнений для формирования умений анализа текстовых категорий (на материале ситуативности) охватывает самостоятельную и коллективную познавательную деятельность и подчинен не только формированию названных умений, но и обогащению научного лексикона, синтаксического строя речи иностранных магистрантов. В самостоятельной учебно-познавательной деятельности студенты выполняют следующие виды работы: а) чтение и осмысление текста, содержащего научную информацию о категории; б) чтение художественного текста, перевод новых слов и выражений; в) чтение текстов для формирования фоновых знаний реципиента; г) выполнение отдельных элементов анализа. В коллективной учебной деятельности (на занятии) упражнения подчинены: а) обогащению научной речи магистрантов (слушание, воспроизведение, запись по памяти необходимых для анализа синтаксических конструкций); в) формированию умения делать элементы анализа; г) осуществлению полного анализа категорий текста.

Перспективы исследования состоят в отборе теоретических сведений об остальных глобальных категориях текста (интенциональности, целостности, членимости, модальности и др.) и разработке методики их анализа, поскольку аналитическая учебная деятельность является базой для формирования профессиональной компетенции филолога.

\section{ЛИТЕРАТУРА}

Вознесенская, И. М. (2011). Ситуативность. В А. К. Рогова (ред.), Текст: теоретические основания и принципы анализа, (сс. 140-176). Санкт-Петербург: Златоуст (Voznesenskaia, I. M. (2011). Situativeness. In A. K. Rogova (Ed.), Text: theoretical foundations and principles of analysis, (pp. 140-176). St. Petersburg: Zlatoust).

Воробьева, О. (1993). Текстовые категории и фактор адресата. Киев: Выща школа (Vorob'eva, O. (1993). Text categories and addressee factor. Kiev: Higher School).

Гак, В. Г. (1998). Высказывание и ситуация. Языковые преобразования, (сс. 243-263). Москва: Школа Языки русской культуры (Gak, V. G. (1998). Statement and situation. Language Conversions, (pp. 243-263). M oscow: School of Languages of Russian Culture).

Гаспаров, Б. М. (1996). Язык, память, образ. Лингвистика языкового существования. Москва: Новое литературное обозрение (Gasparov, B. М. (1996). Language, memory, image. Linguistics of linguistic existence. M oscow: New Literary Review). 
ван Дейк, Т. А., Кинч, В. (1988). Стратегии понимания связного текста. Новое в зарубежной лингвистике, 23, 153-212 (van Dyck, T. A., Kinch, W. (1988). Strategies for understanding a coherent text. New in Foreign Linguistics, 23, 153-212).

ван Дейк, Т. А., Кинч, В. (1983). Стратегия восприятия дискурса. Москва: Наука (van Dyck, T. A., Kinch, W. (1983). Discourse Perception Strategy. M oscow: Science).

Дементьев, В.В. (2006). Непрямая коммуникация. Москва: Гнозис (Dementiev, V. V. (2006). Indirect communication. M oscow: Gnosis).

Долинин, К. А. (2007). Интерпретация текста. Французский язык. Москва: URSS (Dolinin, K. A. (2007). Interpretation of the text. French. M oscow: URSS).

Долинин, К. А. (1999). Речевые жанры как средство организации социального взаимодействия. Жанры речи, 1-5, 7-13 (Dolinin, K. A. (1999). Speech genres as a means of organizing social interaction. Speech Genres, 1-5, 7-13).

Карасик, В. И. (2007). Коммуникативная тональность. Жанры речи, 5, $81-94$ (Karasik, V. I. (2007). Communicative tonality. Speech Genres, 5, 81-94).

Карасик, В. И. (2004). Языковой круг: личность, конщепты, дискурс. Москва : ГНОЗИС (Karasik, V. I. (2004). Language circle: personality, concepts, discourse. M oscow: GNOSIS).

Касавин, И. Т. (2008). Текст. Дискурс. Контекст: введение в социальную эпистемологию языка. Москва: Канон+ (Kasavin, І. Т. (2008). Text. Discourse. Context: an introduction to the social epistemology of language. M oscow: Canon +).

Клюев, Е. В. (2002). Речевая коммуникация. Москва: Рипол Классик (Klyuev, E. V. (2002). Voice communication. Moscow: Ripol Classic).

Кожина, М. Н. Ситуация общения. В М. Н. Кожина (ред.), Стилистический энциклопедический словарь русского языка, (сс. 694). Москва: Наука: Флинта (Kozhina, M. N. The situation of communication. In M. N. Kozhina (Ed.), The Stylistic Encyclopedic Dictionary of the Russian Language, (p. 694). M oscow: Science: Flint).

Костомаров, В. Г. (2005). Наш язык в действии: Очерки современной русской стилистики. Москва: Гардарики (Kostomarov, V. G. (2005). Our language in action: Essays on contemporary Russian stylistics. M oscow: Gardariki).

Красных, В. В. (1997). Коммуникативный акт и его структура. Функциональные исследования, 4, 34-49 (Krasnykh, V. V. (1997). The communicative act and its structure. Functional Studies, 4, 34-49).

Колегаева, И. (1991). Текст как единица научной и художественной коммуникации. Одесса: Обл. упр. отдела по печати (Kolegaeva, I. (1991). Text as a unit of scientific and artistic communication. Odessa: Region control print department).

Селиванова, Е. А. (2002). Основы теории текста и коммуникации. Киев: цул (Selivanova, E. A. (2002). Fundamentals of text theory and communication. Kiev: TSUL).

Стативка, А. М., Мовчан, Т. В. (2018). В поисках эффективной системы упражнений для формирования ключевых компетенций языковой личности студента-инофона: аналитический обзор. Педагогічні науки: теорія, історія, інновачійні технології, 1, 245-255 (Stativka, A. M., Movchan, T. V. (2018). In search of an effective system of exercises for the formation of key competencies of the linguistic personality of a foreign student: an analytical review. Pedagogical sciences: theory, history, innovative technology, 1, 245-255).

Тураева, 3. Я. (2009). Лингвистика текста. Текст: Структура и семантика. Москва: URSS (Turaeva, Z Ya. (2009). Linguistics of the text. Text: Structure and semantics. Moscow: URSS).

Формановская, Н. И. (2007). Речевое взаимодействие: коммуникация и прагматика. Москва: Икар (Formanovskaia, N. I. (2007). Speech interaction: communication and pragmatics. Moscow: Icarus). 
Чернухина, И. Я. (1990). Основы контрастивной поэтики. Воронеж : Изд-во Воронеж. ун-та (Chernukhina, І. Үа. (1990). Fundamentals of contrasting poetics. Voronezh: Publishing house of Voronezh university).

\section{АНОТАЦІЯ}

Статівка Валентина. Текстово-дискурсивна категорія ситуативності: лінгвометодична проекція.

У статті здійснюється аналіз і відбір лінгвістичної інформачії про текстоводискурсивну категорію ситуативності для іноземних магістрантів-фрілологів; презентується розроблена автором методика формування однієї з основних складових професійної компетенції фрілолога - уміння аналізувати текстові категорії (на матеріалі ситуативності). Теоретична інформація з галузі лінгвістики тексту містить як загальноприйняті, так і дискусійні положення, що дозволить викладачеві і магістрантам організувати на занятті наукову дискусію навколо обсягу проблеми текстової категорії ситуативності. Розроблений комплекс вправ використовується як у самостійній, так і колективній пізнавальній діяльності; він підпорядкований збагаченню наукового лексикону, синтаксичного ладу мовлення іноземних магістрантів і формуванню вмінь аналіза текстових категорій.

Ключові слова: лінгвістика текста, категорія ситуативності, комунікативна ситуація, референціальність, антропоцентричність, комплекс вправ, аналіз текстової категорії.

\section{SUMMARY}

Stativa Valentyna. The text-discursive category of temporality: linguistic and methodological projection.

The aim of the article is to select linguistic information about the text-discursive category of situativeness for foreign undergraduates-philologists in order to create a theoretical basis for the formation of the ability to analyze the designated text category. Theoretical information from the field of text linguistics contains both generally accepted and debatable provisions, which allows the teacher and undergraduates to organize a scientific discussion around the raised problem of the volume of the text category of situativeness.

After analyzing the main linguistic and linguistic-methodological works that relate to the problem raised in the article, the author comes to the conclusion: situativeness is a global textual category that intersects with many categories and subcategories (for example, referentiality, anthropocentricity, space and time, intentionality) and therefore in the text they closely interact, complementing one another. In the process of analyzing situativeness, we inevitably have to talk in connection with the sphere of communication, about space and time, about referentiality; in connection with the medium of communication - about anthropocentricity - the addresser and the addressee, the recipient's presupposition, the observer, etc. This understanding of situativeness expands the scope of its content and affects the nature of the analysis.

The article presents the developed by the author methods of formation of skills of analysis of text categories (by the material of situativeness). The developed set of exercises covers independent and collective cognitive activity and is subordinated not only to the formation of these skills, but also to the enrichment of scientific vocabulary, syntactic structure of speech of foreign undergraduates. In independent educational and cognitive activity, students perform the following types of work: a) reading and comprehension of the text containing scientific information about the category; b) reading of literary text, translation of new words and expressions; c) reading of texts for formation of background 
knowledge of the recipient; $d$ ) performance of separate elements of the analysis. In collective educational activities (in the classroom) exercises are subject to a) enrichment of scientific speech undergraduates (listening, playback, recording from memory necessary for the analysis of syntactic structures); c) the individual elements of the analysis; d) a complete analysis of the text category.

Key words text linguistics, category of temporality, communicative situation, referentiality, anthropocentricity, exercises, analysis of text categories.

\section{УДК 378}

\section{Світлана Шмалєй}

Національний педагогічний університет імені М. П. Драгоманова

\section{ПРОБЛЕМИ ВИЩОЇ ОСВІТИ В УМОВАХ ГЛОБАЛІЗАЦІї}

У статті розглядаються основні тенденції організації вищої освіти в сучасному глобалізованому суспільстві. У прочесі дослідження з'ясовано, що сучасна вища освіта детермінується необхідністю розвитку людського капіталу. Установлено, що професійна освіта повинна сприяти розвиткові соціальноособистісних, професійних компетенцій та моральних якостей спеціаліста. Виникають умови для створення інтернаціональної системи освіти, яка формує мобільність, діалогічність, інноваційність студентів. Формується стратегія самостійного пошуку та засвоєння знань. Упроваджуються міжнародні стандарти, експертизи та технології оцінки якості освіти. У дослідницьких університетах виконуються науково-прикладні завдання міждисциплінарного характеру, упроваджуються моделі викладання в дії, навчання на практиці. Модернізація освітнього процесу базується на єдності гуманістичного, особистісно-орієнтовного, міждисциплінарного, компетентнісного та середовищного підходів.

Ключові слова: вища освіта, глобалізація, людський капітал, дослідницький університет.

Постановка проблеми. У постіндустріальну епоху рушійною силою сталого соціально-економічного розвитку $\epsilon$ професійна освіта, яка забезпечує розвиток і відновлення людського потенціалу. Людський капітал визначають як соціально-професійну компетентність спеціаліста. Людський капітал - це сукупність знань та досвіду, ціннісних особистіснопрофесійних якостей спеціаліста, вмотивованого, здатного до пошуку альтернативних шляхів та відповідального щодо ефективного рішення різноманітних соціально-особистісних та професійних задач (Сенашенко, 2013, с. 50; Скотна, 2012, с. 73).

Аналіз актуальних досліджень. Доведено, що людський капітал впливає на економічне зростання суспільства так, як і чинники виробництва. Підвищення ролі професійної освіти в розвиткові людського капіталу зумовлено декількома чинниками. 